\title{
METEOROLOGICAL AND HYDROLOGICAL CHANGES BASED ON EUROPEAN ENVIRONMENT AGENCY (2017)
}

\author{
J. MIKA ${ }^{1}$
}

\begin{abstract}
Regional climate model (RCM) results could not be duly represented by the IPCC 2013 Report, focusing mostly on global climate models (GCM). The aim of our study is to provide a literature insight into these types of results, based on the recent Report by the EEA (2017). After a brief comparison of the GCMs and RCMs, averages of short- and long-term projections of temperature and precipitation changes are provided. Hydrological changes are represented by run-off, mountain glaciers and snow mass. These and other, non-hydrological impacts are also listed from the Report. This short review, delimited by the length, page size and colouring of the hardcopy, is finishing by the experienced destruction caused by the weather extremes over Europe. The original sources, together with the EEA quotations are referred.
\end{abstract}

Keywords: climate change, Europe, RCM, extreme events, hydrological impacts

\section{INTRODUCTION}

Climate change is one of the most problematic processes of our century. Its past and likely future processes are surveyed by the IPCC WGI (2013) Report. The maps of the regional changes are, however, mostly based on a wide set of coupled global ocean-atmosphere models (OA-GCMs), whereas regional climate models (RCM) embedded into GCMs are less represented. This neglecting means that the better resolved computations stay mostly out of scope of the Report.

The aim of our study is to show projections by the RCMs, comprehended by the recent EEA Report (2017). Before going to the basic experience with the GCM simulations in Section 2, we repeat the new scenarios compared to the older ones (this Section). Temperature and precipitation projections based on the CORDEX regional climate model simulations are seen in Section 3, with hydrological impacts on run-off, mountain glaciers and snow mass in Section 4. Projections of both latter Sections are accompanied by observed tendencies. Qualitative summary and effects of extreme events are presented in Section 5.

The EEA (2017) Report accepts the so called RCP scenarios which are related to the scenarios applied in the previous IPCC Reports as indicated in Fig. 1. One can establish that the most radical RCP8.5 is slightly above the 2nd strongest previous A1 scenario to the radiative forcing and temperatures changes, as well. The scenarios RCP6.0 and RCP4.5 overlap from above and from below the mildest B1 scenario of the previous set. The most optimistic, RCP2.6 scenario, that projects decreasing radiative forcing and stagnating global mean temperature after 2040, has no similar mate among the SRES scenaria used by the former IPCC scenaria.

\footnotetext{
${ }^{1}$ Eszterhazy Karoly University, H-3300 Leanyka 6, Eger, Hungary. mika.janos@ @uni-eszterhazy.hu
} 

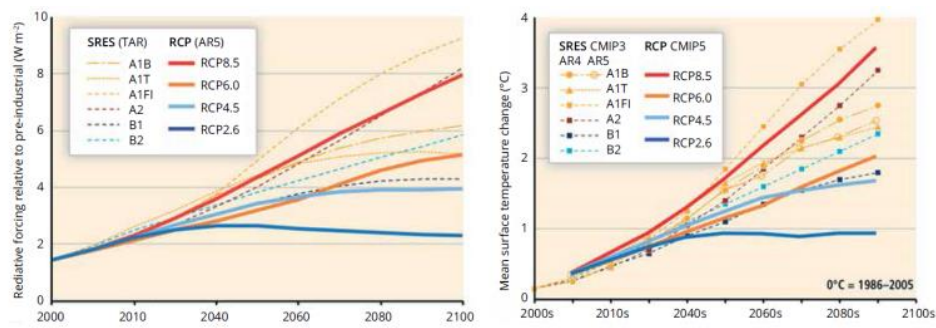

Fig. 1. Projected radiative forcing (left) and global mean surface temperature change (right) over the 21st century using the Special Report on Emissions Scenarios (SRES) and representative concentration pathway (RCP) scenarios. (IPCC WGII, 2014: Fig 1.4)

\section{GCM VS. RCM COMPARISON}

Projections of the future climate depend both on the emission scenarios and differences between behaviour of the climate models. At shorter time-scales (e.g. the 2040s) the effects of inter-model differences prevail, but by the end of the century (the 2040s) difference in the scenarios can also make difference (Fig. 2).

Even for such large spatial averages differ considerably according to the different model runs with the same scenario and time lapse. Note the difference in the sign of precipitation changes between northern and southern parts of Europe.
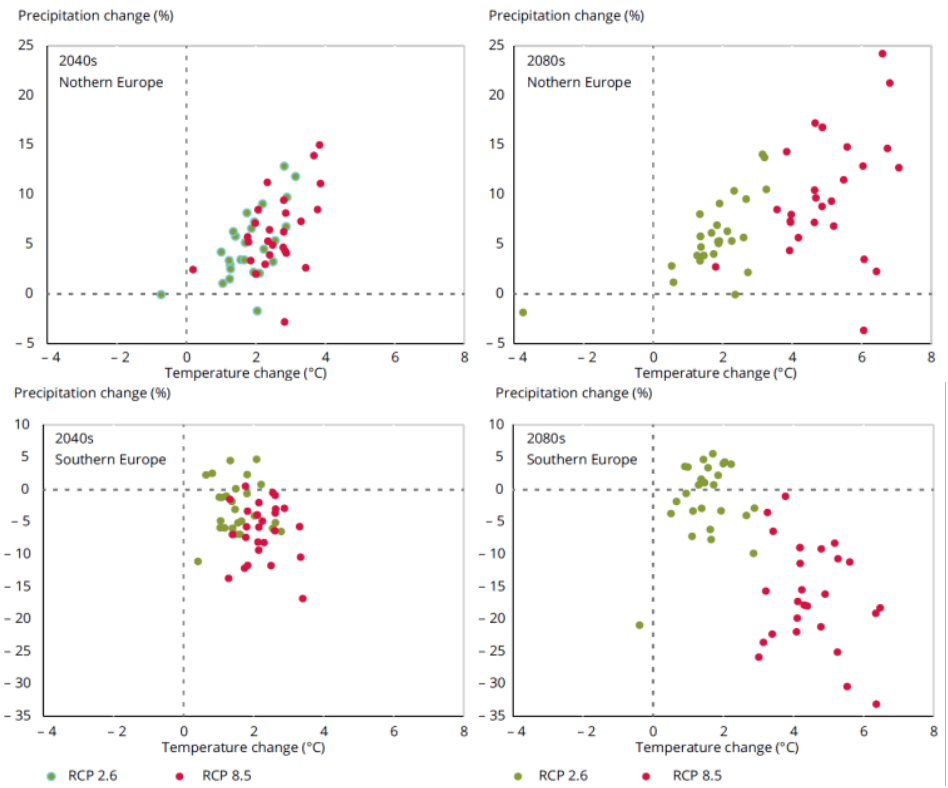

Fig. 2. Projected changes in annual temperature and precipitation for northern Europe and southern Europe and for two time periods relative to 1961-1990. Each point is from a global model projection in the CMIP5 dataset (as used in the IPCC AR5) using either a high (RCP8.5) or low (RCP2.6) forcing scenario. Only models in the CMIP5 that had projections for both scenarios were used. (UK Met Office, EEA, 2017: Fig. 3.4) 
Quantitative impact studies apply a chains of various models, output data of one model serves as input data for the other. Global climate models are often of too coarse resolution to provide meaningful input for the impact models. Hence, dynamical downscaling, i.e. regional climate models should be interfaced (Fig. 3). This means one-sided embedding of fine resolution (10-25 km grid-point distance) models into the global model, generally characterised by $100 \mathrm{~km}$ grid-point distances. Changes in the regional model are not fed back to the mainframe model.

The key question of mezo-scale modelling is whether this compromise, i.e. that the fine resolution is applied over a part of the globe, only, can lead to better results than achieved by the GCMs. Fig. 4, providing projections of wind speed by ensembles of both scale models, does not directly give the answer to the question, but it clearly illustrates that the same and larger absolute changes in the regional simulations are of lower significance than those by the GCMs. This means that the inter-model variability stronger among the RCMs than among the GCMs.
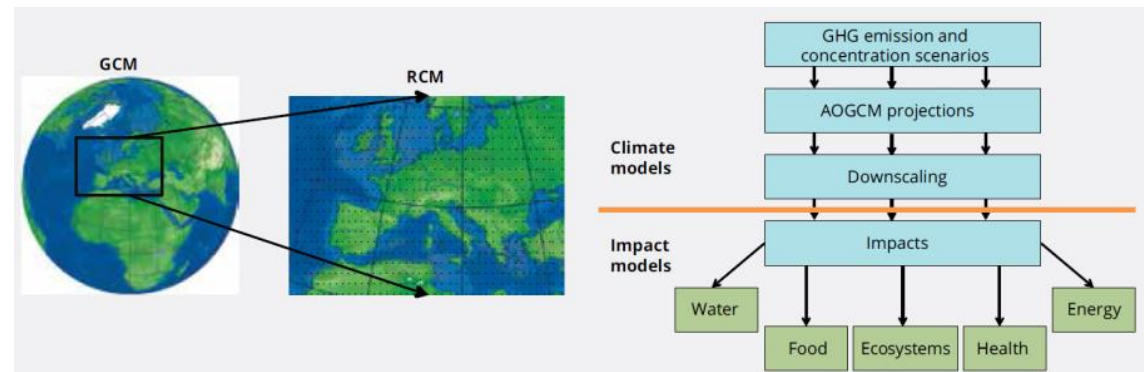

Fig. 3. Scheme of modelling climate change and its impacts. AOGCM: atmosphere-ocean general circulation model; GHG: greenhouse gas. (EEA, 2017: Fig 3.3)

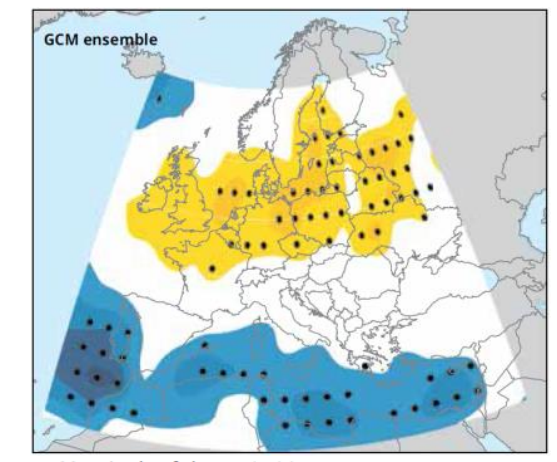

Magnitude of change $(\mathrm{m} / \mathrm{s})$

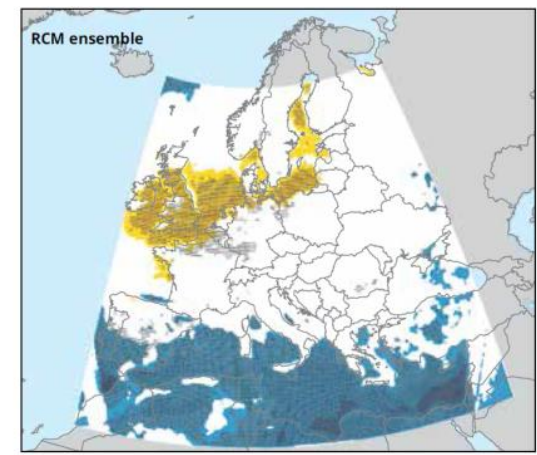

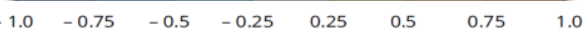

- Statistical significance above 0.95

Fig. 4. Projected changes in extreme wind speed (98th percentile of daily maximum wind speed) based on GCM and RCM ensembles for A1B (2071-2100) relative to 1961-2000. Left: ensemble mean of changes based on 9 GCMs. Right: the same based on 11 RCMs. Colored areas indicate the change $(\mathrm{m} / \mathrm{s})$. Statistical significance at the $5 \%$ level is shown by black dots. (Adapted from Donat, Leckebusch et al., 2011, EEA, 2017: MAP 3.11) 


\section{METEOROLOGICAL CHANGES}

\subsection{Temperature changes}

As it was seen in Fig. 2, the long-term projections clearly depend on the applied emission scenario, hence Fig. 5 presents those for RCP8.5 changes, only. Spatial distribution of the projected temperature changes is rather different in summer and winter. The summer maxima occur in the Mediterranean region, with much smaller changes over the higher mostly plain latitudes. In winter, however, the strongest warming, reaching $6 \mathrm{~K}$, are simulated over the Russian plain with an obvious decrease towards the oceans.
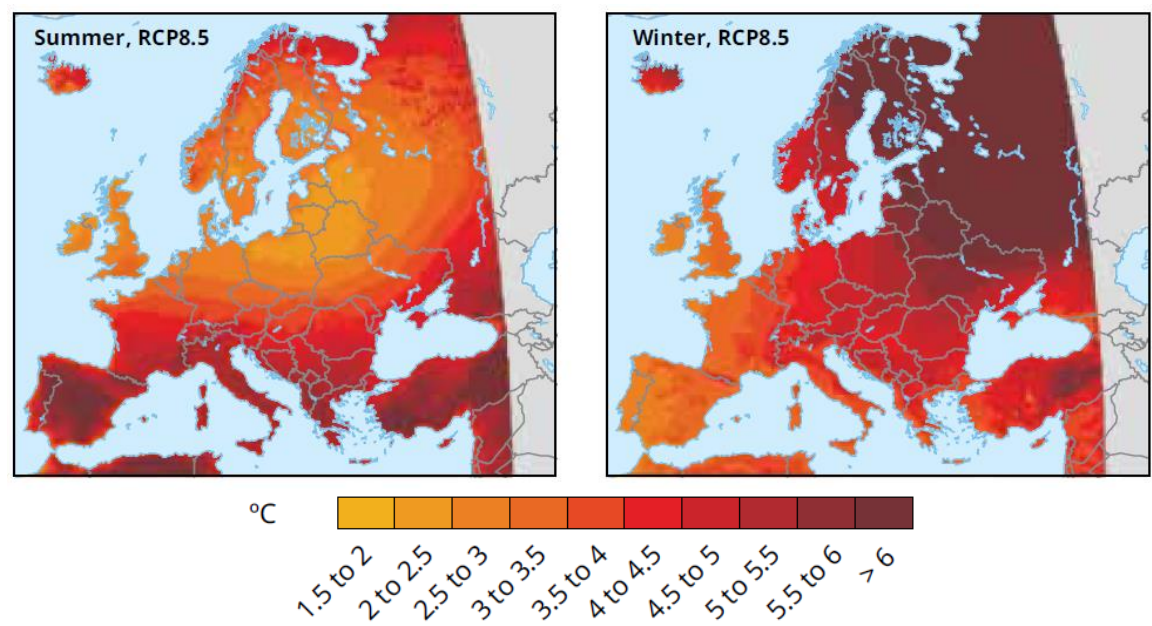

Fig. 5. Projected changes in summer (left)and winter (right) air temperature $\left({ }^{\circ} \mathrm{C}\right.$ ) near the surface in 2071-2100 compared with 1971-2000 for the scenarios RCP8.5. The maps indicate the multi-model ensemble averages of many combined GCM-RCM simulations from the EURO-CORDEX initiative. (Jacob et al., 2014, EEA, 2017: MAP 3.4)
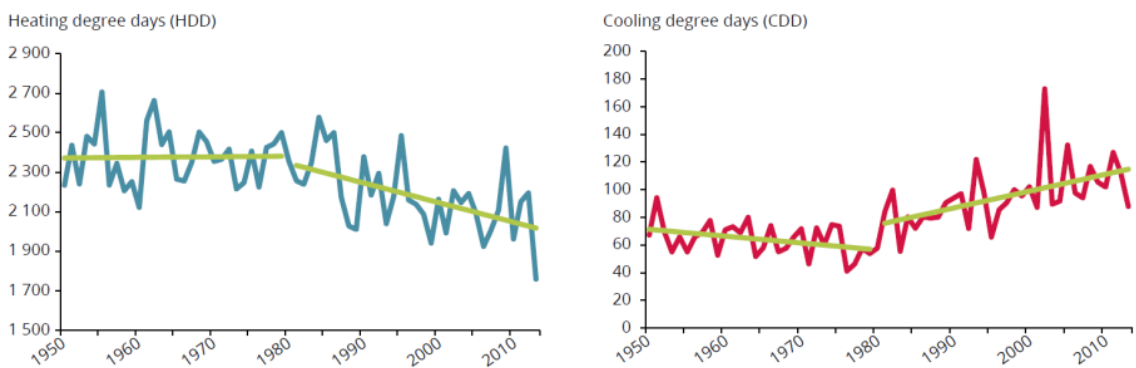

Weighted HDD 1951-2014 Trend 1951-2014 $\mid$ Weighted CDD 1951-2014

Fig. 6. Time series of population-weighted heating (left) and cooling degree days (right) averaged over Europe (EU-28 without Cyprus, but including Liechtenstein, Norway and Switzerland) over 1951-2014, including linear trends for 1951-1980 and 1981-2014 JRC, KNMI-ECA\&D: version 11 and Eurostat GEOSTAT 2011 dataset. EEA, 2017: Fig. 5.8) 


\subsection{Precipitation changes}

Regional climate projections (Fig. 7) show annual mean precipitation increase over most of the continent with a decrease over a part of the Mediterranean region. The direction of spatial differences is similar for the summer simulations, but the drying areas are wider, and the wetter areas become limited to the Northern latitudes.

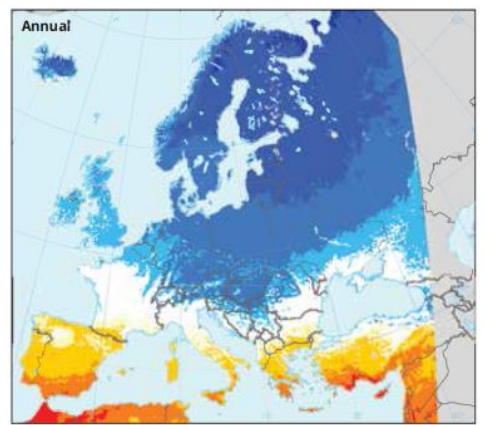

$\%$

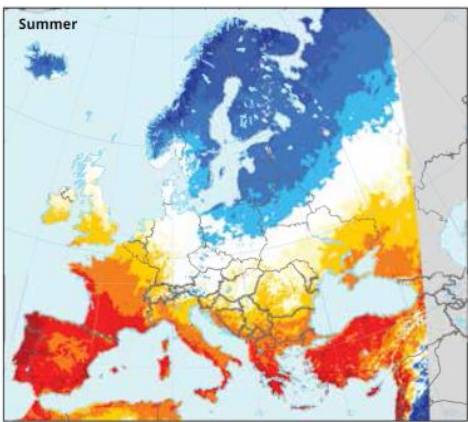

Outside coverage

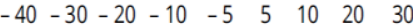

Fig. 7. The same as Fig. 5 for precipitation (\%) (Jacob et al., 2014, EEA, 2017: MAP 3.8)

\section{HYDROLOGICAL CHANGES}

\subsection{Changes in run-off}

Regional climate model reconstructions in 1963-2000, were put into hydrological models to simulate past changes of run-off (Fig. 8). Northern and Western Europe indicated run-off increase, with decrease in Eastern and mostly in Southern Europe.

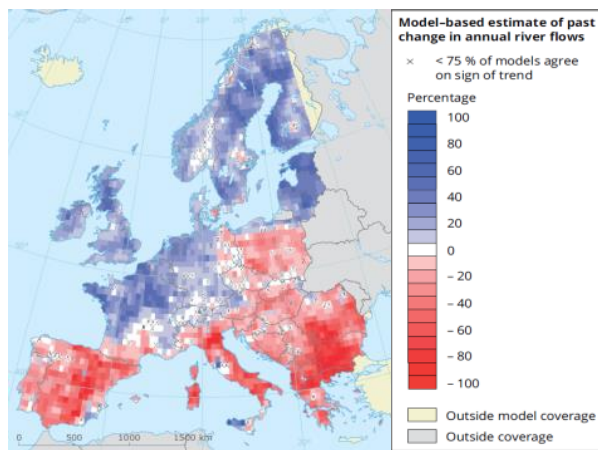

Fig. 8. Model-based ensemble mean trend in annual run-off from 1963 to 2000. ' $x$ ' denotes grid cells where less than three-quarters of the hydrological models agree on the direction of the trend. (Adapted from Stahl et al., 2012. EEA, 2017: MAP 4.7)

Uneven spatial distribution of past run-off and future precipitation is present in future run-off changes (Fig. 8), too. Sign and seasonal distribution are 
rather different in the selected main rivers of Europe. Note the difference between natural changes and the one that considers the water use, as well.

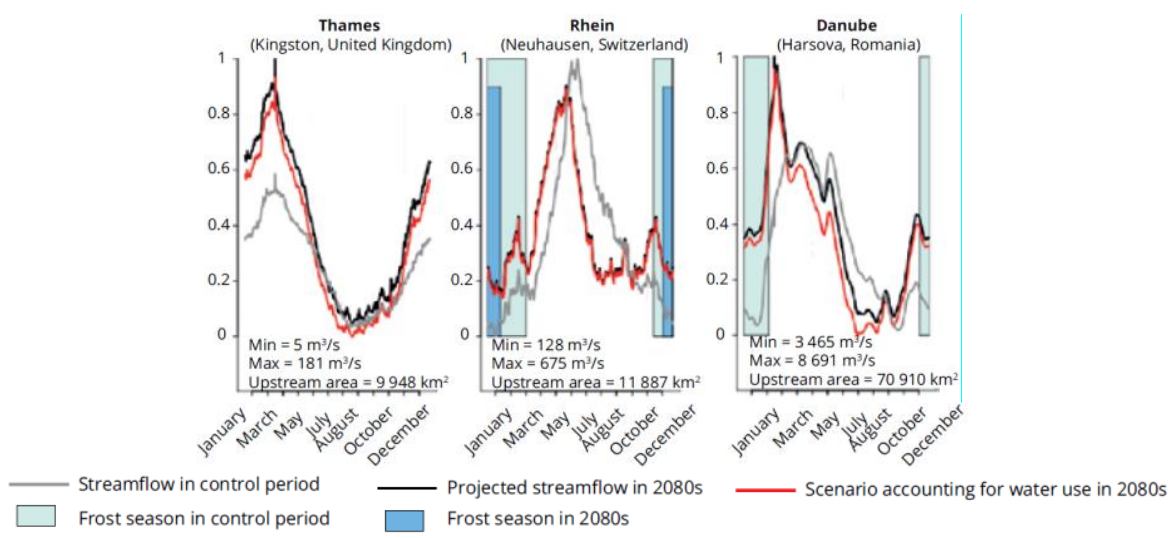

Fig. 9. Projected change in seven-day average river streamflow at three European river monitoring stations in the control period and the 2080s, with and without accounting for projected changes in water use. Shaded areas indicate the frost season in both periods.

(Adapted from Forzieri et al., 2014. EEA, 2017: selection from Fig. 4.11)

\subsection{Changes in mountain glaciers and snow cover}

Mountain glaciers are mostly reducing due to the ongoing warming, but some of them, strongly fed by the enhanced precipitation in northern Europe are thickening (Fig 10a). In the mountains of Central Europe further melting is projected (Fig 10b)

a)

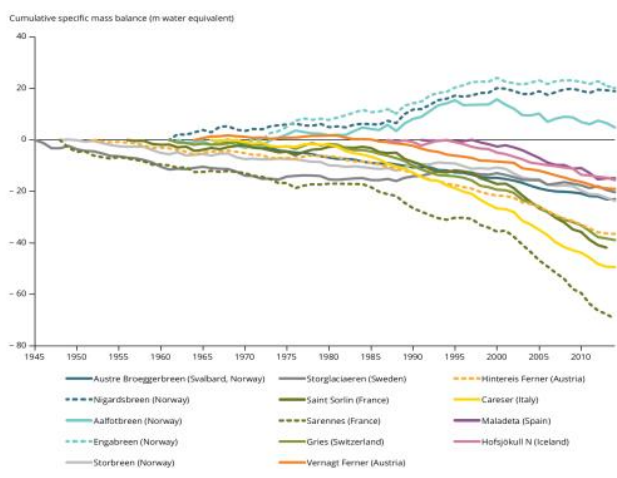

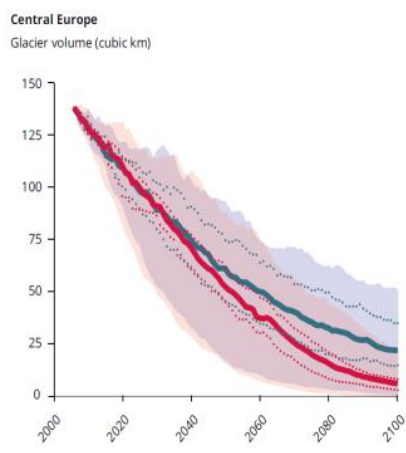

b)

Fig. 10. (left) Cumulative mass balance equivalent ( $m$ of water) of European mountain glaciers in the period 1946-2014. (Fluctuation of Glaciers Database, World Glacier Monitoring Service, EEA, 2017: Fig. 3.12). (right) Projected change in the volume of mountain glaciers in Central Europe (i.e. European Alps and Pyrenees) for 2006-2100, derived using a mass balance model driven by temperature and precipitation scenarios from 14 GCMs. (Radić et al., 2014. EEA, 2017: selected from Fig. 3.13) 
Finally, snow mass of non-mountainous areas monotonically decreases (Fig. 11)

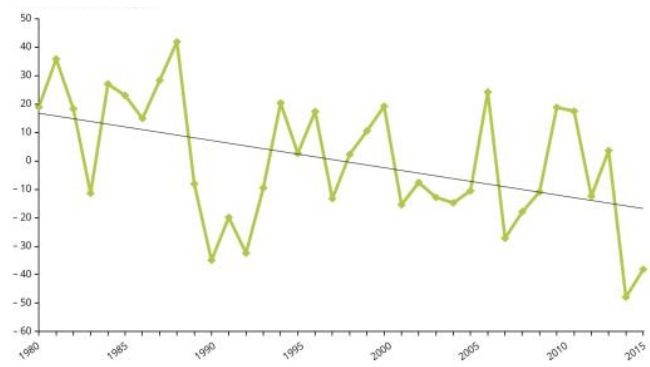

Fig. 11. Trend in March satellite derived snow mass anomaly in Europe for 1980 2015 relative to the 1980-2012 average, excluding mountain regions. GlobSnow, updated from Luojus et al., 2011. (EEA, 2017: Fig. 3.15)

\section{CONCLUDING SYNTHESES}

The EEA (2017) Report displays all experienced and projected impacts established by the scientific literature (Fig. 12), where the mountainous regions are separated.

The Report also provides population-weighted statistics on distribution of various weather extremes and their effect on human life and destruction (Tab. 1).

\begin{tabular}{|c|c|c|}
\hline $\begin{array}{l}\text { Arctic region } \\
\text { Temperature rise much larger than } \\
\text { global average } \\
\text { Decrease in Arctic sea ice coverage } \\
\text { Decrease in Greenland ice sheet } \\
\text { Decrease in permafrost areas } \\
\text { Increasing risk of biodiversity loss } \\
\text { Some new opportunities for the exploitation } \\
\text { of natural resources and for sea transportation } \\
\text { Risks to the livelihoods of indigenous peoples } \\
\text { Coastal zones and regional seas } \\
\text { Sea level rise } \\
\text { Increase in sea surface temperatures } \\
\text { Increase in ocean acidity } \\
\text { Northward migration of marine species } \\
\text { Risks and some opportunities for fisheries } \\
\text { Changes in phytoplankton communities } \\
\text { Increasing number of marine dead zones } \\
\text { Increasing risk of water-borne diseases } \\
\text { Mediterranean region } \\
\text { Large increase in heat extremes } \\
\text { Decrease in precipitation and river flow } \\
\text { Increasing risk of droughts } \\
\text { Increasing risk of biodiversity loss } \\
\text { Increasing risk of forest fires } \\
\text { Increased competition between different water } \\
\text { Increasing water demand for agriculture } \\
\text { Decrease in crop yields } \\
\text { Increasing risks for livestock production } \\
\text { Increase in mortality from heat waves } \\
\text { Expansion of habitats for southern disease vecto } \\
\text { Decreasing potential for energy production } \\
\text { Increase in energy demand for cooling } \\
\text { Decrease in summer tourism and potential incre } \\
\text { Increase in multiple climatic hazards } \\
\text { Most economic sectors negatively affected } \\
\text { High vulnerability to spillover effects of climate c } \\
\text { from outside Europe }\end{array}$ & $\begin{array}{l}\text { Boreal region } \\
\text { Increase in heavy precipitation events } \\
\text { Decrease in snow, lake and river ice cover } \\
\text { Increase in precipitation and river flows } \\
\text { Increasing potential for forest growth } \\
\text { and increasing risk of forest pests } \\
\text { Increasing damage risk from winter storms } \\
\text { Increase in crop yields } \\
\text { Decrease in energy demand for heating } \\
\text { Increase in hydropower potential } \\
\text { Increase in summer tourism } \\
\text { sers }\end{array}$ & $\begin{array}{l}\text { Mountain regions } \\
\text { Temperature rise larger than European } \\
\text { average } \\
\text { Decrease in glacier extent and volume } \\
\text { Upward shift of plant and animal species } \\
\text { High risk of species extinctions } \\
\text { Increasing risk of forest pests } \\
\text { Increasing risk from rock falls and } \\
\text { landslides } \\
\text { Changes in hydropower potential } \\
\text { Decrease in ski tourism }\end{array}$ \\
\hline
\end{tabular}

Fig. 12. Key observed and projected climate change and impacts in the seven main regions of Europe (EEA, 2017: MAP ES1) 
Table 1. Number of death per million people due to extreme weather events by European sub-regions over the period 1991-2015. The region groupings see below the table. Population rates calculated using population data from 2013. Sources: EM-DAT, Eurostat and WHO. For the http: addresses see the references. (EEA, 2017: Table 5.2)

\begin{tabular}{|c|c|c|c|c|c|}
\hline & $\begin{array}{c}\text { Flood and } \\
\text { wet mass } \\
\left.\text { movement ( }{ }^{a}\right)\end{array}$ & Cold event & Heat wave & Storm & Wildfire \\
\hline Eastern Europe & 8.57 & 28.27 & 11.39 & 1.73 & 0.54 \\
\hline Northern Europe & 0.99 & 1.67 & 11.17 & 2.48 & 0.01 \\
\hline Southern Europe & 6.75 & 0.92 & 177.98 & 1.19 & 0.97 \\
\hline Western Europe & 2.09 & 0.89 & 191.58 & 2.79 & 0.04 \\
\hline Total & 4.64 & 5.31 & 128.98 & 1.99 & 0.46 \\
\hline
\end{tabular}

(a) Includes landslides

Eastern Europe: Bulgaria, the Czech Republic, Hungary, Poland, Romania, Slovakia; Northern Europe: Denmark, Estonia, Finland, Iceland, Ireland, Latvia, Lithuania, Norway, Sweden, the United Kingdom; Southern Europe: Albania, Bosnia and Herzegovina, Croatia, Cyprus, Greece, Italy, FYR of Macedonia, Montenegro, Portugal, Serbia, Slovenia, Spain, Turkey; W-Europe: Austria, Belgium, France, Germany, Luxembourg, Netherlands, Switzerland

\section{REFERENCES}

1. Donat, M. G., Leckebusch, G. C., Wild, S. and Ulbrich, U., 2011, 'Future changes in European winter storm losses and extreme wind speeds inferred from GCM and RCM multi-model simulations', Natural Hazards and Earth System Science 11(5), 1351-1370

2. EEA (2017): Climate change, impacts and vulnerability in Europe 2016. An indicatorbased report. European Environment Agency, 419 pp.

3. Forzieri, G., Feyen, L., Rojas, R., Flörke, M., Wimmer, F. and Bianchi, A., 2014, 'Ensemble projections of future streamflow droughts in Europe', Hydrology and Earth System Sciences 18(1), 85-108 (doi: 10.5194/hess-18-85-2014).

4. IPCC, WG I, 2013, Climate change 2013: The physical science basis. Contribution of Working Group I to the Fifth Assessment Report of the Intergovernmental Panel on Climate Change, Cambridge University Press, Cambridge; New York.

5. IPCC, WG II, 2014, Climate change 2014: Impacts, adaptation and vulnerability. Contrib. of Working Group II to the Fifth Assessment Report of the Intergovernmental Panel on Climate Change, Cambridge University Press, Cambridge; New York.

6. Jacob, D., Petersen, J., Eggert, B., Alias, A., Christensen, O. B., Bouwer, L. M., Braun, A., Colette, A., Déqué, M., Georgievski, G., Georgopoulou, E., Gobiet, A., Menut, L., Nikulin, G., Haensler, A., Hempelmann, N., Jones, C., Keuler, K., Kovats, S. et al., 2014, 'EURO-CORDEX: New high-resolution climate change projections for European impact research', Regional Environmental Change 14(2), 563-578

7. Luojus, K., Pulliainen, J., Takala, M., Lemmetyinen, J., Kangwa, M., Sohlberg, R., Nagler, T., Rott, H., Derksen, C., Wiesmann, A., Metsämäki, S. and Bojkov, B., 2011,GlobSnow Final Report. Deliverable 3.5, European Space Agency Study Contract Report ESRIN Contract 21703/08/I-EC, GlobSnow.

8. Radić, V., Bliss, A., Beedlow, A. C., Hock, R., Miles, E. and Cogley, J. G., 2014, Regional and global projections of twenty-first century glacier mass changes in response to climate scenarios from global climate models, Climate Dynamics 42(1-2), 37-58

9. Stahl, K., Tallaksen, L. M., Hannaford, J. and van Lanen, H. A. J., 2012, 'Filling the white space on maps of European runoff trends: Estimates from a multi-model ensemble', Hydrology and Earth System Sciences 16(7), 2 035-2 047

10. http://ec.europa.eu/eurostat/web/population-demography-migration-projections/population-data (Eurostat)

11. http://www.emdat.be/database (EM-DAT)

12. http://www.euro.who.int/en/data-and-evidence (WHO) 